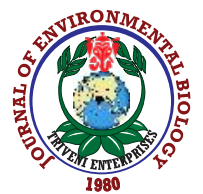

\title{
Review on the ecology and taxonomy of sessile rotifers (Rotifera) with special reference to Mexico
}

\author{
S.S.S. Sarma ${ }^{1 *}$, M.A. Jiménez-Santos ${ }^{2}$, S. Nandini' and R.L. Wallace ${ }^{3}$ \\ ${ }^{1}$ Laboratory of Aquatic Zoology, National Autonomous University of Mexico, CP-54090 Tlalnepantla, México \\ ${ }^{2}$ Posgrado en Ciencias del Mar y Limnología, Universidad Nacional Autónoma de México, CP-04510, Mexico \\ ${ }^{3}$ Department of Biology, Ripon College, Ripon, WI54971-0248, USA
}

*Corresponding Author Email : sarma@unam.mx

\section{Abstract}

Although comprising $<0.5 \%$ of all the known species of Rotifera, sessile rotifers are an important component in freshwater ecosystems, especially shallow waterbodies. During the last eight decades, fewer than 80 publications have dealt specifically with sessile rotifers, while more than 7600 articles have focused on rotifers in general.

In this work research on the sessile rotifers with emphasis on the Mexican fauna has been reviewed and some additional information on the new records has been included. Difficulties involved in collection and maintenance of sessile rotifers, as well as problems of identification and quantification have been considered. Published data on the ecology and taxonomy of this group has also been reviewed.

There are 35 species of sessile rotifers from three families Atrochidae, Collothecidae, and Flosculariidae, but to that four more species in the planktonic family Conochilidae may be added, as recent molecular research indicates that this family lies within Flosculariidae. The inventory includes new records for Mexico and one poorly described species.

The number of sessile rotifer species known from Mexico is still low considering the large number of shallow water bodies present in Mexico. Comments regarding the importance of substratum (macrophyte) type and the significance of physical structure in providing substratum for larval stages of sessile rotifers have been made.

Key words: Distribution, Freshwater ecosystem, Macrophytes, Mexico, Sessile rotifers

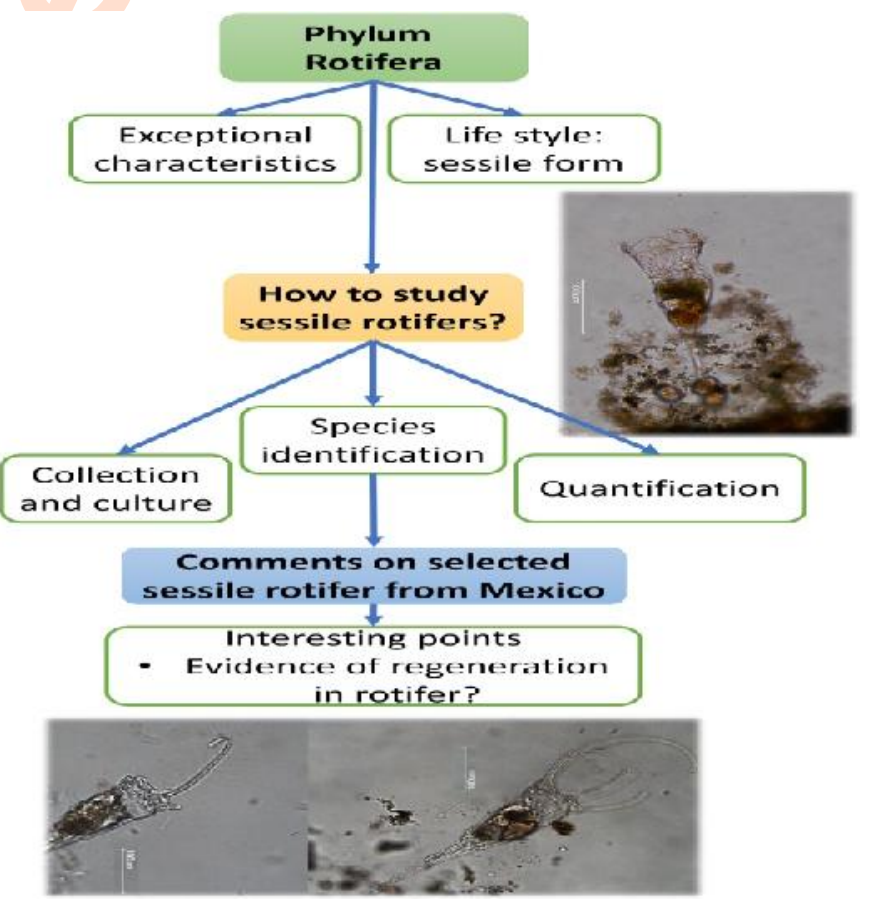

How to cite : Sarma, S.S.S., M.A. Jiménez-Santos, S. Nandini and R.L. Wallace: Review on the ecology and taxonomy of sessile rotifers (Rotifera) with special reference to Mexico. J. Environ. Biol., 41, 3-12 (2020). 


\section{Introduction}

Phylum Rotifera is a group of micrometazoans of about 2000 species with exceptional characteristics that make them model organisms in basic and applied research, including aging, ecology, evolution, systematics, biodiversity, aquaculture, and ecotoxicology (Wallace et al., 2015; Declerck and Papakostas, 2017). Some of these characteristics are their small size within Metazoa $(40-3000 \mu \mathrm{m})$, presence of a muscular pharynx (mastax) with jaws (trophi), and three modes of reproduction (Wallace et al., 2015). Reproduction is exclusively sexual in species of small marine family Seisonidae. On the other hand, in the four families of Bdelloidea reproduction is exclusively asexual. With 30 families, Monogononta comprises the bulk of Rotifera. In this group most reproduction is parthenogenetic, but in many (but not all) species, this asexual pattern is broken by brief periods of sex with the production of haploid eggs. If one of these eggs remains unfertilized a male develops, but if it is fertilized, a diapausing, resting stage (resting egg) develops. These cyst-like structures have a mean volume of $\sim 6.8 \times 10^{5} \mu \mathrm{m}^{3}$, but their known volumes many range from 0.1 to $97.4 \times 10^{5} \mu^{3}$ (Walsh et al., 2017). Once released from the parent, a resting egg (RE) sinks to the bottom of the habitat where it remains until conditions are suitable for hatching.

Survivorship reduces with aging, but some REs may remain viable for decades (Wallace et al., 2006). In ephemeral habitats that dry, winds can loft REs along with dust and sand and disburse them many kilometers downwind (Rivas, Jr. et al., 2018, 2019). Extraordinary resistance to harsh conditions is also seen in bdelloids. They occur in extreme conditions (e.g., frozen waters, thermal springs, hypersaline waters, etc.) (Wallace et al., 2006). Bdelloids also have been shown to withstand ionizing radiations of >1000 Gy, (e.g., Philodina roseola: Gladyshev and Meselson, 2008). Collectively rotifers occupy a range of habitats. They may be free living in the plankton and/or benthos, epiphytic, epizoic, ectoparasitic (e.g., fish gills), or endoparasitic (e.g., in colonial algae such as Vaucheria and Volvox or animals such as aquatic oligochaetes and snail eggs) (May, 1989; Rao, 1993; Wallace et al., 2001). Their feeding strategies coupled with short lifespan ( $<4$ weeks) and short generation time (days to 2 weeks), rapid growth rates, and numerical abundance results in their central trophic position in freshwater ecosystems and their vital importance in aquaculture (Sarma and Nandini, 2017).

Studies on the ecology and taxonomy of rotifers focus on planktonic species usually based on formalin-fixed samples. However, many species possess a soft body wall (illoricate); these species lose their shape upon fixing and, thus, become nearly unidentifiable (Wallace et al., 2006; 2015). Besides their soft lorica, study of sessile rotifers is further complicated by the habitat in which they are found, mainly macrophytes, which are frequently ignored in routine limnological investigations (Walsh et al., 2008). Though there are about 100 sessile rotifer species, i.e., $<0.5 \%$ of all rotifers, they play an important role as planktonic taxa in energy transfer, perhaps more so in shallow waterbodies. By feeding on algae, diatoms, and detritus they transfer energy to higher trophic levels, which otherwise can be expected to pass through the detrital cycle or microbial loop (Wallace et al., 2015). Indeed popular literature depicts many sessile rotifers as nature's water purifiers (Walsh, 1979). In spite of this, literature on rotifers is strongly biased towards planktonic taxa. For example, information retrieved from the Web of Science, reveals that though the global study of rotifers is on the rise, that of sessile rotifers is lagging (Fig. 1). During the last eight decades, approximately 70 publications deal specially with this group. The study of sessile rotifers has been emphasized by researchers in just four countries; USA, Belgium, India, and Thailand (37, 10, 8, and 5 publications respectively). Mexico, like the rest of the world, has not only limited information on this group but also scattered in different journals.

Aquatic plants offer substratum for a wide variety of both, peripheral and epiphytic organisms. The structural complexity of macrophytes also serves as a refuge against predation (Walsh, 1995) and are a rich source of food resources due to their high epiphytic phytoplankton diversity (Jeppesen et al., 1998). Mexico has a great diversity of macrophytes (hydrophytes) (Lobato-de Magalhães and Martínez, 2018), which can potentially house many sessile rotifers but have been ignored in rotifer diversity studies (Walsh et al., 2008). Here studies on diversity of sessile rotifers in Mexico with emphasis on some salient taxonomic features, sampling strategies, identification, and quantification have been reviewed and with some data on the new records. Because study of sessile rotifers involves live individuals, some aspects of their culture techniques have been included here.

\section{Collection and Maintenance}

For most species, study of sessile rotifers require living individuals and depending on the type of macrophyte being examined, the entire submerged plant, should be collected. For floating macrophytes, of course, this means that the roots are sampled and observed. In some cases, macrophytes from the field can be kept in a bucket of pond water with mild aeration to maintain suitable oxygen concentrations. This technique may release attached species from the plant into the water column, which can be then filtered out ( $\mathrm{H}$. Segers, personal communication). However, this is partially successful because many species are permanently attached to macrophytes. Note that any forceful attemptat detaching specimens can result in their damage.

Rotifers associated with macrophytes collected from the field can be maintained in aquaria without providing additional food such as algae because they depend on periphytic algae and detrital matter and associated organisms such as bacteria. Depending on the volume of the aquarium and the amount of plant material no aeration may be needed. However, care should be taken to prevent anoxic conditions from developing; in that case the plant material will decompose and cause complete deterioration of the system and a decline in rotifer species richness and density. Sessile rotifers collected from the eutrophic waterbody, Lake Xochimilco survive for longer than a month by 
replacing $50 \%$ of lake water with synthetic medium such as EPA (Sarma et al., 2017). However, frequent replacement (e.g., weekly) of medium is required. Using this technique, several sessile rotifers were maintained for more than a month, although quantitative analysis of specie abundance was not always carried out.

\section{Species identification}

For identification of sessile species the literature of Wallace et al., $(2016,2019)$ and Koste $(1978)$ was used, but those keys were aumented with works that review the taxonomic status of specific groups: Flosculariidae (Floscularia and Ptygura: Segers et al., 2010; Meksuwan, 2011; Limnias: Wallace et al., 2018; Meksuwan et al., 2018), Collothecidae: Meksuwan et al., 2013) and Conochilidae: Meksuwan et al., 2015). Taxonomic status was confirmed using the Rotifer World Catalog (Jersabek and Leitner, 2013). Living individuals may be studied by carefully separating tiny segments of macrophytes to which sessile species are attached and placing the plant material in a drop of source water (Edmondson, 1944). If a coverglass is placed over

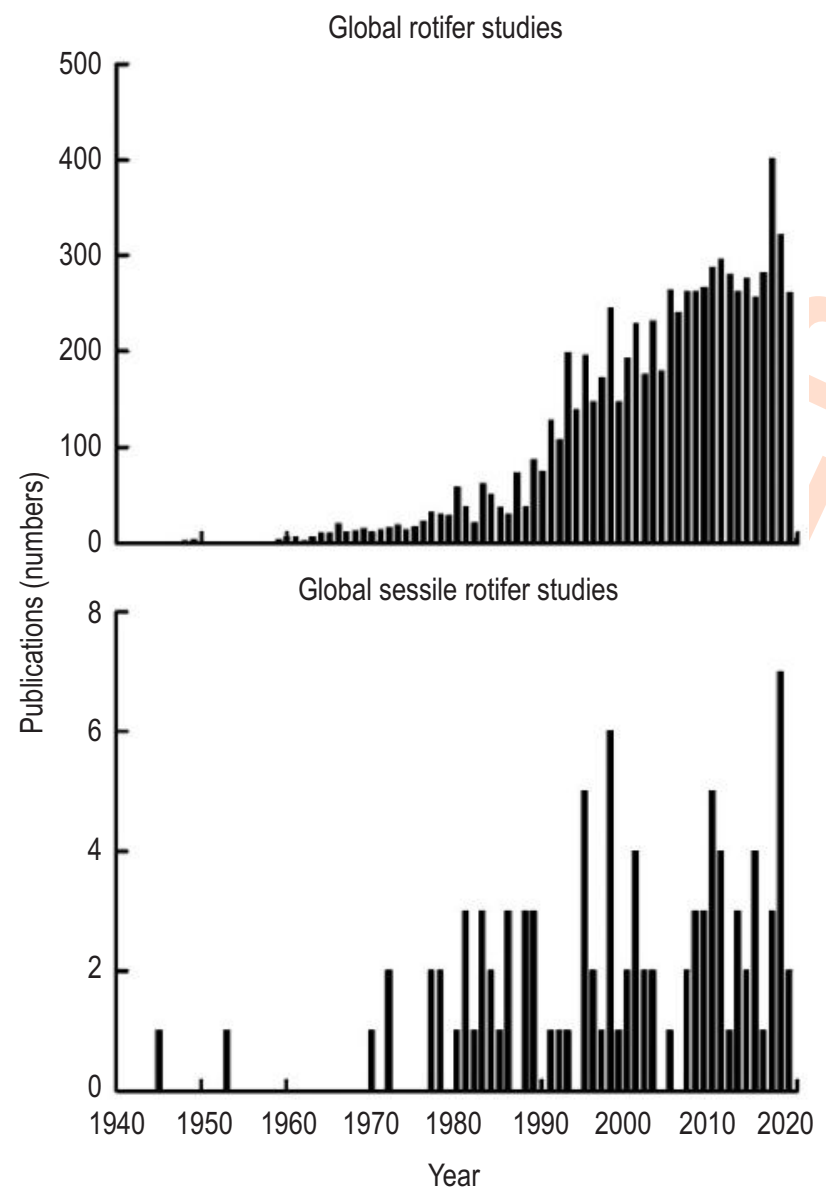

Fig. 1: Published studies on rotifers: Data obtained from Web of Science (1900-2019). Data retrieved using the word rotifer* (upper panel), rotifer* AND sessile (lower panel). the specimen, care should be taken so that the animal is not crushed (Wallace et al., 2006). When observed under a microscope, many specimens remain in contracted state, but usually become fully extended within few minutes. Selected living specimens can later be transferred onto a slide under an optical compound microscope (10X20 or 10X40 magnification) for their determination at species level. Generally, the shape of the crown, as well as the presence of lobes or protuberances such as hooks and knobs are used for determination of species. For some species, structure of tube in which they live can be a strong identification of genus and sometimes species. Examining the morphology of trophi using light microscope does not aid in identification unless a catalogue of their form has been prepared previously from live specimens. However, there are tools such as geometric morphometry which can help delimit species (Zelditch et al., 2012).

Ecological characterization of species is possible, but it is a laborious procedure. Jiménez-Santos et al. (2019a) studied the effects of temperature on three morphotypes of Limniasceratophylli and a single morphotype of Limnias cf. melicerta. Their results showed that optimal temperature levels differed among the morphotypes. At $20^{\circ} \mathrm{C}$, morphotype 1 had the highest population growth rates $(r)\left(0.23 d^{-1}\right)$, while morphotype 3 had the lowest $\left(0.15 \mathrm{~d}^{-1}\right)$. For $L$. cf. melicerta, r was higher at $25^{\circ} \mathrm{C}$ than at $20^{\circ} \mathrm{C}$. Of three morphotypes of $L$. ceratophylli, morphotype 3 had the highest $r$ at $25^{\circ} \mathrm{C}$. Molecular approach to detect cryptic speciation is largely restricted to loricated taxa such as Brachionus (Mills et al., 2017). Except for few cases, sessile species have not been studied in great detail. Similar kind of results have been reported by Meksuwan et al. (2015) and Kordbacheh et al. (2018).

\section{Quantification}

Compared to planktonic taxa, quantification of sessile rotifers is more complicated and prone to different errors depending on the method used. The problems start with the assumption that sessile rotifers are uniformly distributed over the surface of a given macrophyte. Some species are attached only to a specific site on the macrophyte (e.g., leaves, stem, or roots). The second problem is expression of sessile taxa in terms of biomass. For planktonic taxa, geometric formulae are largely used (Ruttner-Kolisko, 1977) for biomass derivation or it is possible to individually weigh the specimens for dry weight determination (Dumont et al., 1975). For sessile species such techniques are ineffective as they include large errors while separating the specimens from their tube or assuming their geometric shape.

Quantification of density of individuals associated with a given macrophyte can be reported in three ways: volume of the plant, surface area of the plant, and volume of the water immediately surrounding the plant. Determining the volume of the plant is the easiest of these three procedures. The volume of water displaced by a macrophyte is determined simply by observing the increase in water volume in a graduate cylinder when the plant is submerged. Later, the number of leaves and/or roots (in free-floating species) is counted, and rotifer 


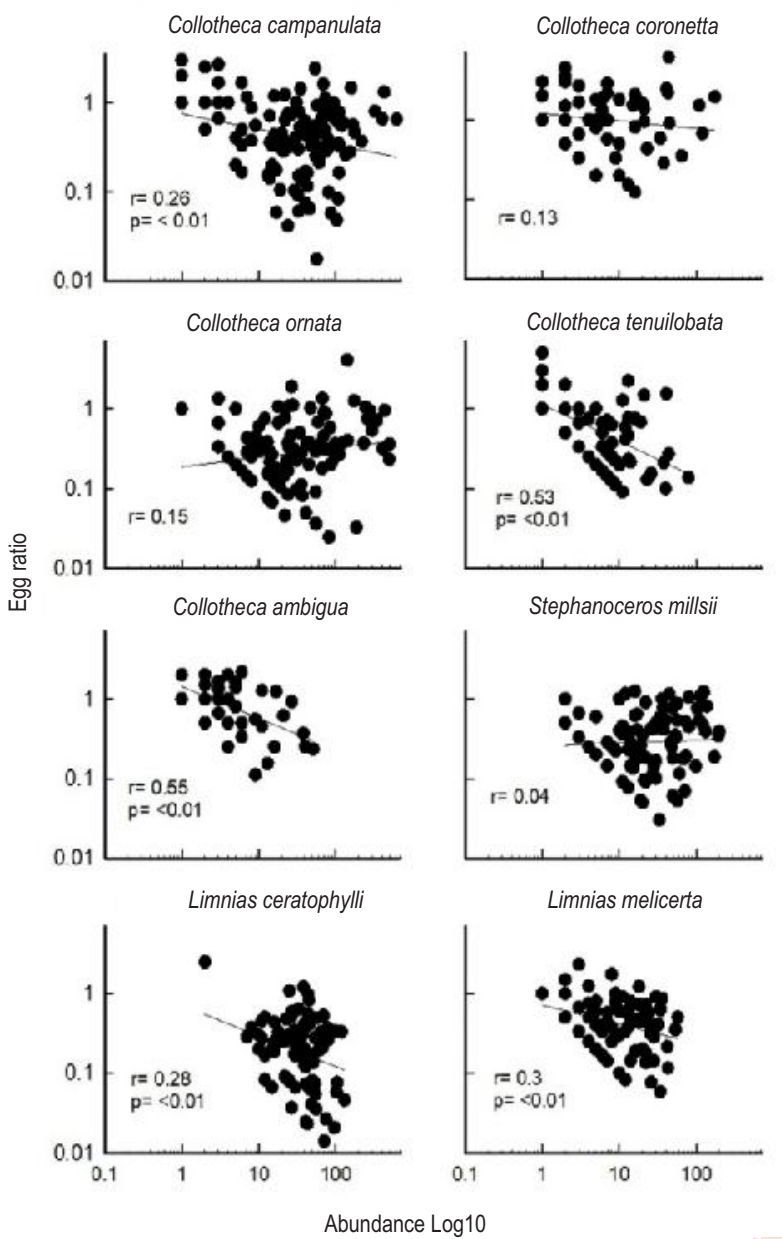

Fig. 2: Egg ratio (eggs-female) and abundance of dominant species (Jiménez-Santos et al., 2019b).

density is attributed to biovolume of plant to which sessile species are attached. This was done by Jiménez-Santos et al. $(2019 b)$ in their study of sessile rotifers attached to water hyacinth, Eichhornia crassipes. In cases where the roots or stems of macrophytes are long, it is appropriate to divide them into distinct sections to understand the distribution of sessile species (Edmondson, 1945; Wallace, 1977).

The density of rotifers may be expressed as a function of area of plants to which the rotifers have attached, but this raises its own procedural problems. The area for some macrophyte leaves can be measured by calculations based on their geometric shapes, e.g., various lily pads (Wallace, 1977). Area may also be determined by arduously tracing the outline of the plant on paper and then determining the area by planimetry (Edmondson, 1945). However, for plants with highly dissected leaves, such as Myriophyllum, calculating the area by this method is tedious. Fortunately, the surfactant-weight method of Harrod and Hall

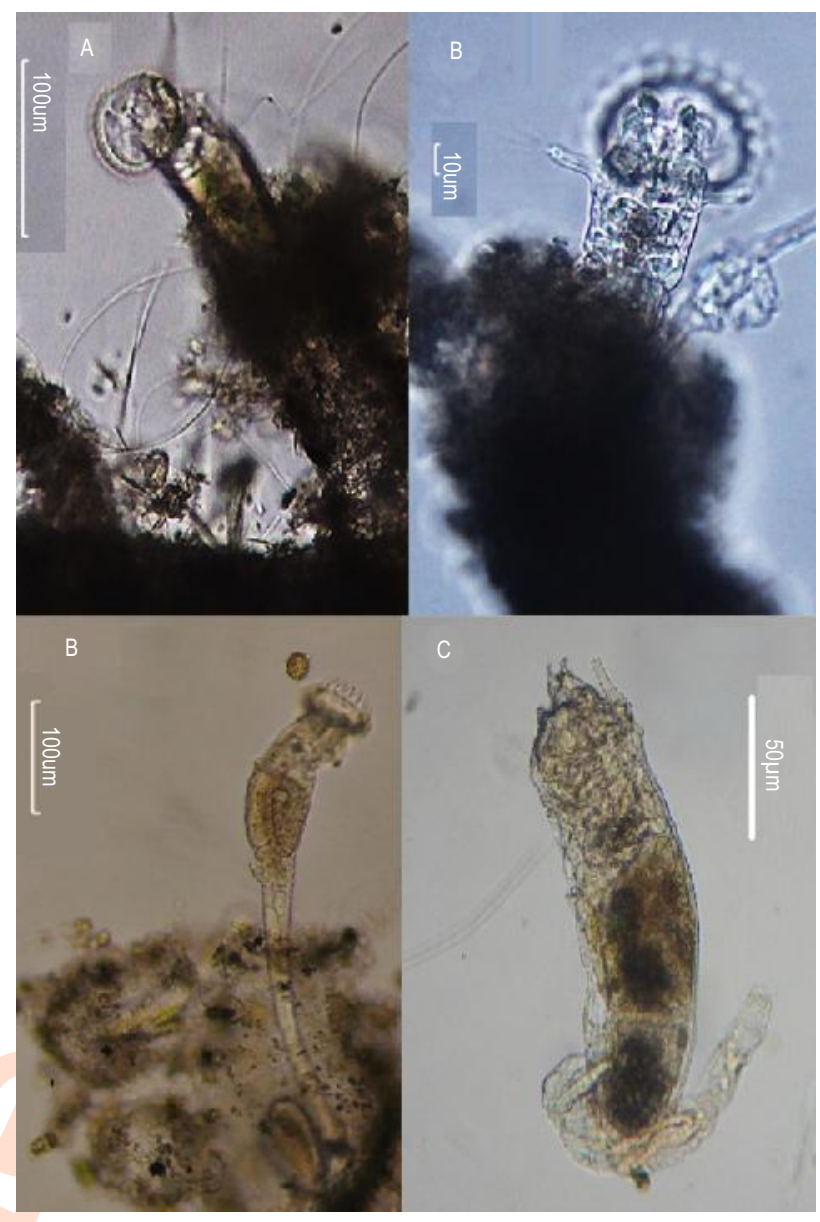

Fig. 3: Selected sessile rotifer species from Lake Xochimilco. Family Flosculariidae: (A) Ptygura beauchampi; (B) Ptygura longicornis; (C) Ptygura melicerta and (D) Ptygura cf. linguata.

(1962) may be used to determine the surface area of many macrophytes (Wallace, 1977). A variation of this method has been described by Watala and Watala (1994). In their procedure, a solution of Coomassie Brilliant Blue (a non-permeable, highmolecular weight dye) is prepared. When the plant material is submerged in the solution the dye is adsorbed onto the surface of the plant in proportion to its surface area. Thus, difference between dye concentration in the solution before submerging the plant and after may be used to estimate the plant's surface area.

The third way to consider the density of sessile rotifers attached to a plant is to calculate the volume of water immediately surrounding the hydrophyte. To do this one imagines a cylinder enclosing the tips of the leaves (and/or roots) running the entire length of the plant. The base of this cylinder has an area that is multiplied by plant length to get the enclosed volume. Using this technique, Edmondson (1944) calculated the maximum population of sessile individuals in a liter of water to be $\sim 25,000$; this value is 


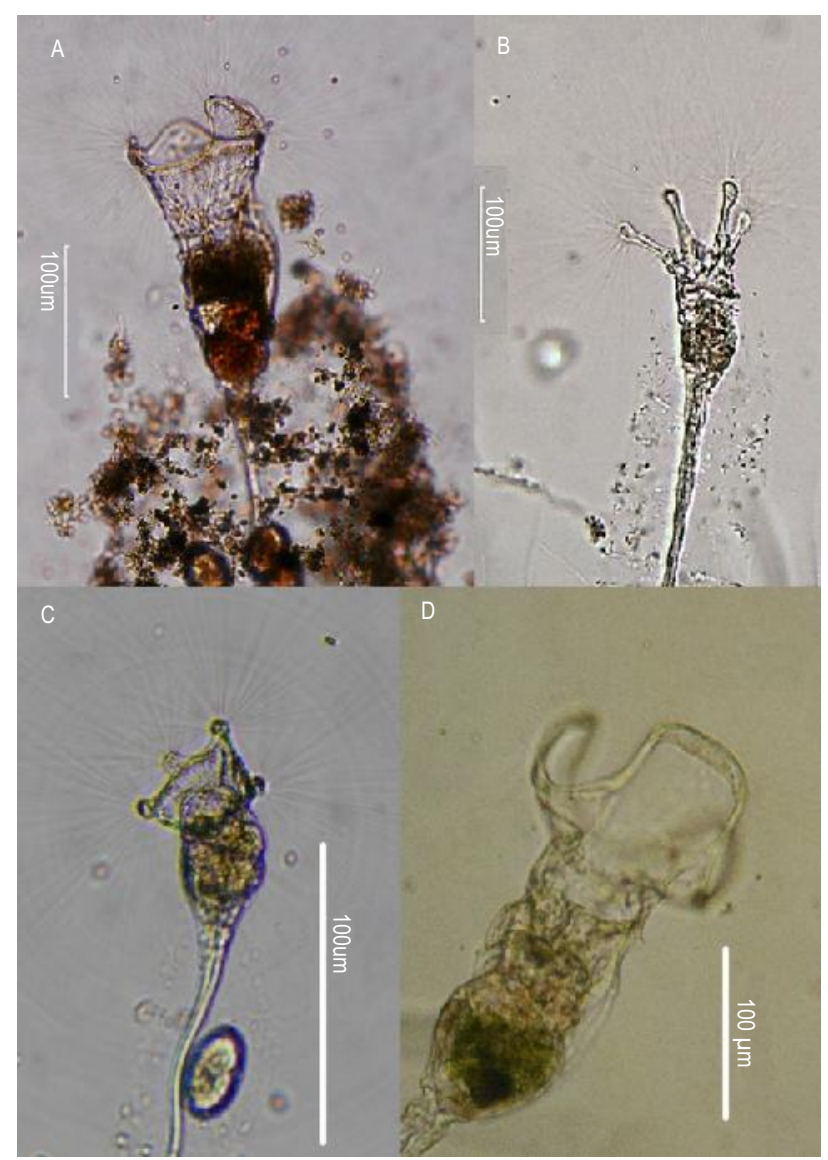

Fig. 4: Selected sessile rotifer species from Lake Xochimilco. Family Collothecidae: (A) Collotheca ambigua; (B) Collotheca tenuilobata; (C) Collotheca ornata and (D) Collotheca trilobata.

much greater than that present in natural planktonic communities. Quantification of sessile species must be carried out as soon as collections are made, usually within $48 \mathrm{hrs}$ after collection.

This is because there may be underestimation of population densities of sensitive taxa that rarely survive once removed from their natural habitat. The ratio of number of parthenogenetic eggs to those of females of zooplankton species, also called egg ratio (Edmondson, 1968), has been widely used as an indicator of available food, growth phase of population, or stress (Sarma et al., 2005). Though, the egg ratio was specifically developed for planktonic organisms, its application has been extended to non-planktonic species too. Rapid estimation of sessile rotifer abundances will also determine egg ratio because they deposit eggs in a gelatinous sac (e.g., Collotheca), a tube (e.g., Floscularia, Limnias), or on specific position on the foot (oviferon) (e.g. Sinantherina). When this was applied to the data of JiménezSantos et al. (2019b), 6 out of 8 sessile species (C. campanulata, C. ambigua, C. tenuilobata, S. millsii, L. ceratophylli and L. melicerta)

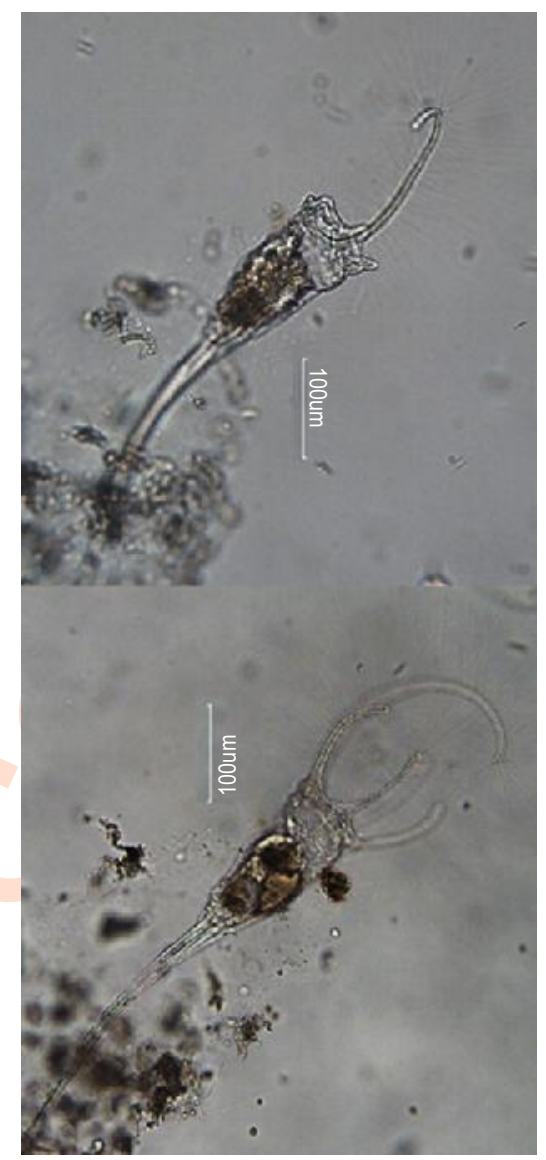

Fig. 5: Stephanocerosmillsii from Lake Xochimilco with only one lobe (left photo). The same individual after $24 \mathrm{hr}$ showing some regrowth of other lobes (right photo).

had a significantly inverse relation between the egg ratios and population density (Fig. 2). This suggests that sessile rotifers too suffer from density-dependent adverse effects on reproduction (Sarma et al., 2005).

\section{Macrophytes as a substrate}

Relationship of sessile species and their substrate has not been explored well (Wallace, 1980; Meksuwan et al., 2014). While some sessile rotifers settle on several macrophyte species, a few are known to have curious substrate preferences. A few examples serve to illustrate this point. Edmondson (1944, 1945) showed that several species prefer Utricularia (vulgaris) macrorhiza and also that Floscularia conifera shows a preference for tubes of conspecifics. In some habitats, Collotheca (gracilipes) campanulata settles on the under surface of Elodea canadensis leaves (Wallace and Edmondson, 1986). On the other hand, absence of sessile species on certain macrophytes may be due to (1) their removal 
Table 1: Updated list of sessile rotifer species known from Mexico

\begin{tabular}{|c|c|}
\hline Rotifer species & Selected references \\
\hline \multicolumn{2}{|l|}{ Collothecaceae Harring, 1913} \\
\hline \multicolumn{2}{|l|}{ Atrochidae Harring, 1983} \\
\hline Cupelopagis vorax (Leidy, 1857) & Sarma (1999) \\
\hline Atrochus tentaculatus Wierzejski, 1893 & Espinosa-Rodriguez (2019)1 \\
\hline \multicolumn{2}{|l|}{ Collothecidae Harring, 1913} \\
\hline Collotheca ambigua (Hudson, 1883) & Jiménez-Santos et al. (2019b) \\
\hline Collotheca campanulata (Dobie, 1849) & Jiménez-Santos et al. (2019b) \\
\hline Collotheca coronetta (Cubitt, 1896) & Ríos-Arana et al. (2019) \\
\hline Collotheca crateriformis Offord, 1934 & Wallace et al. (2008) \\
\hline Collotheca ornata (Ehrenberg, 1832) & García-Morales and Elías-Gutiérrez (2004) \\
\hline Collotheca pelagica (Rousselet, 1983) & Rico-Martínez and Silva-Briano (1993) \\
\hline Collotheca riverai Vilaclara y Sládeček, 1989* & Vilaclara and Sládecek (1989) \\
\hline Collotheca tenuilobata Anderson, 1889 & Jiménez-Santos et al. (2019b) \\
\hline Collotheca trilobata (Collins, 1872) & Present study \\
\hline \multicolumn{2}{|l|}{ Flosculariaceae Harring, 1913} \\
\hline \multicolumn{2}{|l|}{ Conochilidae Harring, 1913} \\
\hline Conochilus coenobasis (Skorikov, 1914) & Rico-Martínez and Silva-Briano (1993) \\
\hline Conochilus dossuarius Hudson, 1885 & Torres-Orozco and Zanatta (1998) \\
\hline Conochilus natans (Seligo, 1900) & Sarma (1999) \\
\hline Conochilus unicornis Rousselet, 1892 & Torres-Orozco and Zanatta (1998) \\
\hline \multicolumn{2}{|l|}{ Flosculariidae Ehrenberg, 1838} \\
\hline Beauchampia crucigere (Dutrocet, 1812) & Jiménez-Santos et al. (2019b) \\
\hline Floscularia melicerta (Ehrenberg, 1832) & Jiménez-Santos et al. (2019b) \\
\hline Limnias ceratophylli Schrank, 1803 & Wallace et al. (2008) \\
\hline Limnias melicerta Weisse, 1848 & Sarma et al. (2017) \\
\hline Octotrocha speciosa Thorpe, 1893 & Sarma and Elias-Gutiérrez (1998) \\
\hline Ptygura beauchampi Edmondson, 1940 & Jiménez-Santos et al. (2019b) \\
\hline Ptygura brachiata (Hudson, 1886) & Muñoz-Colmenares et al. (2017) \\
\hline Ptygura crystallina (ehrenberg, 1834) & Jiménez-Santos et al. (2019b) \\
\hline Ptygura brevis (Rousselet, 1893) & Wallace et al. (2008) \\
\hline Ptygura furcillata (Kellicott, 1889) & Sarma and Elías-Gutiérrez (1998) \\
\hline Ptygura libera Myers, 1934 & García-Morales and Elías-Gutiérrez (2004) \\
\hline Ptygura cf.linguata Edmonson, 1939 & Present study \\
\hline Ptygura longicornis (Davis, 1867) & Jiménez-Santos et al. (2019b) \\
\hline Ptygura melicerta Ehrenberg, 1832 & Nandini et al. (2017) \\
\hline Ptygura tacita Edmondson, 1940 & Sarma (1999) \\
\hline Ptygura tridorsicornis Summerfiel-Wright, 1957 & Garza-Mouriño and Castellanos-Páez (2003) \\
\hline Ptygura velata (Gosse, 1851) & Wallace et al. (2008) \\
\hline Sinantherina ariprepes Edmondson, 1939 & Jiménez-Santos et al. (2019b) \\
\hline Sinantherina semibullata (Thorpe, 1893) & Sarma and Elías-Gutiérrez (1999) \\
\hline Sinantherina socialis (Linnaeus, 1758) & Sarma (1999) \\
\hline
\end{tabular}

by abrasion (e.g., from the under surfaces of lily pads) (Wallace, 1980), (2) predatory activities by snails (Wallace, 1980) and/or (3) allelopathic plant exudates (Van Donk and Van de Bund, 2002; Gao et al., 2017, Sarma and Nandini, 2018). Thus, to confirm selection of substrate, it is necessary to conduct experiments based using larval stages of sessile taxa such as Limnias (Sarma et al., 2017).

\section{Ecology of sessile rotifers}

Ecological research on sessile rotifers began in earnest with the classic works of Edmondson $(1944,1945)$. Since then, ecological research on these species, either in field or laboratory studies, has not kept pace with those of free-swimming counterparts (see Lampert, 1997; Wallace et al., 2019). Demographic aspects of sessile rotifers such as survival and reproduction depend on the initial colonization abilities of freeswimming larval forms. Selection of substrate and response to abiotic changes in the environment are critical for larval and subsequently adult survival. The habitats offered by macrophytes has been little explored in sessile taxa. It is known that for freeliving non-sessile rotifer Euchlanis dilatata, the reproductive behavior depends on the macrophyte (Walsh, 1995). For sessile rotifers, this may vary depending on where the substrate is 
located. Wallace (1980) reported that Ptygura beauchampi prefers Gloeotrichia sp. to Utricularia in lakes, but follows opposite trend in ponds. The specific place on a macrophyte may also be critical. Wallace (1978) showed that Ptygura beauchampi preferred to settle on only one of three types of trap doors of Utricularia (vulgaris) macrorhiza. It has been observed that $P$. beauchampi is associated with Chara in mesotrophic waterbody. Thus, different patterns in ecological, ethological, and evolutionary strategies of larval settlement in sessile taxa is expected (Young et al., 2019).

Different substrates influence the population dynamics and demographic variables of sessile rotifers. Biotic factors such as food concentration and type also determine the growth of rotifers. For example, Limnias ceratophylli and L. melicerta have higher population growth rates $\left(0.16\right.$ day $\left.^{-1}\right)$ at higher algal levels

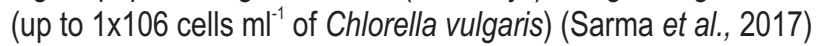
Abiotic factors such as temperature have profound effect on the demographics of sessile rotifers as shown in 3 morphotypes of $L$. ceratophylli at 20 and $25^{\circ} \mathrm{C}$ (Jiménez-Santos et al., 2019a). In field conditions too, sessile species respond rapidly to variations in abiotic factors. For example, Jiménez et al. (2019b) have found that the community of sessile rotifers associated with Eichhornia crassipes is significantly influenced by temperature, dissolved oxygen, $\mathrm{pH}$, turbidity and transparency.

Survival of sessile taxa is regulated by substrate type which offers stable conditions for food availability and protection against predation, as well as by the interaction among the individuals of same species. Two examples illustrate this phenomenon: (1) Floscularia conifera has a longer average life when it forms colonies compared to solitary individuals that are attached directly to the plant (Edmondson, 1945). (2) Specimens of $C$. campanulata that have been induced to settle on the upper surface of $E$. canadensis leaves do not live as long as those settled on the under surface (Wallace and Edmondson, 1986).

Also, sessile rotifers tend to have longer lifespans than planktonic species: e.g., under optimal conditions, the life of span of sessile rotifers can be longer than 40 days ( $L$. ceratophylli and L. melicerta (Sarma et al., 2017), while for planktonic species it is about weeks. Fitness of a rotifer specie is often associated with its reproductive rates. The highest population growth rates can be found among the species of genus Brachionus that can increase up to 2 per day. Predatory rotifers of genus Asplanchna also have higher growth rates (<1.5 per day). However, smaller planktonic taxa such as Anuraeopsis fissa have relative lower rates (0.2-0.5 per day). The growth rates of sessile rotifers appear to be within this range (0.15-0.38 per day) (Sarma et al., 2017; Jiménez-Santos et al., 2019a).

\section{Description of selected species of sessile rotifers from Mexico}

To date, the recorded number of sessile rotifer species from Mexico is 35, representing three families (Table 1; Fig 2)
Flosculariidae (20 species) Collothecidae (9 species), Conochilidae (4 species) and Atrochidae (2 species). Sessile rotifers from the Lake Xochimilco are noteworthy because this waterbody is composed of system of shallow canals offering diverse possibilities to the stability of macrophytes. Ptygura beauchampi (Edmondson), 1940. This species is distributed in the Nearctic, Neotropic, Palearctic, and Oriental regions. In the Lake Xochimilco it is present throughout year, except August. They usually occur in low densities; species small ( $<200 \mu \mathrm{m})$ with a dorsal gap in ciliated corona (Fig. 3A).

Ptygura cf. linguata (Edmonson, 1939), a specimen resembling $P$. linguata was found in San Luis Potosí, but its antennae were shorter than those reported in P. linguata (Fig. 3 D). The species has two distinguishing characteristics: two long antennae and two hooks on the head region. P. linguata was originally described from America, but was also reported from Southeast Asia, with some variation in its morphology (Seger et al., 2010). Ptygura longicornis (Davis, 1867) is a species with extensive biogeographical distribution: Australian, Nearctic, Neotropical, Palearctic, and Oriental. It was recorded from the Lake Xochimilco from July to December. This rotifer builds a granular tube as in P. crystallina but with long antennae (Fig. 3 B). Ptygura melicerta (Ehrenberg, 1832) is a cosmopolitan species from Xochimilco with characteristics similar to $P$. melicerta var. socialis (Koste, 1978). Infraspecific forms are known: P. melicerta melicerta and P. melicerta ctenoida (Segers, 2007). It was recorded during winter months (January to March). Species forming colonies of 2 to 5 individuals; tube not well-developed; a dorsal gap on the corona wide (Fig. 3C).

Fig. 3. shows selected sessile rotifer species from Lake Xochimilco. Family Flosculariidae (A) Ptygura beauchampi, (B) Ptygura longicornis, (C) Ptygura melicerta and (D) Ptygura cf. linguata. The recent work of Meksuwan et al. (2013) in Thailand details diagnostic features of Collothecidae including some SEM images of trophi and dichotomic key for identification of species of this family. Collotheca ambigua (Hudson, 1883) is found in most of the biogeographical areas, but not in the Pacific and Antarctic regions. In this study this species was found mostly during the months of March to June. Species have foot as long as body; corona five-lobed, one longer than others (Fig. 4A). Collotheca tenuilobata Anderson, 1889. Distributed in Afrotropical, Australian, Nearctic, Neotropical, and Palearctic regions. It was found during March to November in Lake Xochimilco. Coronal lobes long with knob-shaped terminations (Fig. 4B). Collotheca trilobata (Collins, 1872). Distributed worldwide, Species with 3 clearly separated broad lobes, with depth cavity among the lobes large (Fig. 4D). Fig. 4 shows selected sessile rotifer species from Lake Xochimilco. Family Collothecidae: (A) Collotheca ambigua, (B) Collotheca tenuilobata, (C) Collotheca ornata and (D) Collotheca trilobata.

Stephanoceros millsii (Kellicott, 1885) is an interesting species with five long lobes. Sometimes the lobes can be unequal in length. An individual with a single coronal lobe, but as long as 
the body it self, was observed (Fig. 5). The individual was separated and transferred to EPA medium containing low densities of mixed algae Monoraphidium sp. and Chlorella vulgaris. After $24 \mathrm{hr}$, the individual was observed again and found that the remaining four missing lobes had begun to develop as in regular specimens of $S$. millsii, although one of them was still longer than the others. Regeneration of lobes of this species has also been reported by Tiefenbacher (1972).(NB: See also the work of Sartory and Hollowday (1983) for comments regarding the specimen of Collotheca monoceros as merely a damaged Stephanoceros fimbriatus (Goldfuss, 1820). This demonstrates the importance of observing living organisms in determining their taxonomic status and, thus, can clarify the status of uncertain species. Distribution of sessile rotifers on a single macrophyte species illustrates its ability to provide a suitable habitat. For example, in the roots of floating macrophyte Eichhornia crassipes, Koste (1975) found about 70 rotifer species, including 15 sessile species. In Lake Xochimilco 18 sessile rotifers were found to be associated with the same macrophyte species. Thus, 6 species were added to the list of sessile rotifers from Mexico (details of sampling: Jiménez-Santos et al., 2019).

The taxonomic richness of sessile rotifers from Mexico represents about $30 \%$ of the world sessile rotifer fauna (around 100 species: Segers, 2007). Edmondson (1944), a pioneer on rotifer ecology and taxonomy, studied about 100 localities in USA and reported about 50 sessile species. In Brazil, as many as 53 sessile species have been reported (Garraffoni and Lourenço, 2012). In Mongolia, Jersabek (2010) reported 11 sessile rotifers. In Tehran (Iran), some species of sessile rotifers are described (8 species) (Kordbacheh and Rahimian, 2012). Nearly, an equal number of sessile rotifers have been documented in Thailand (Sa-Ardrit et al., 2013) and in India (about 27 sessile rotifer species) exist (Sharma, 2014). Obviously, the Mexican studies are based on few waterbodies and rely on sporadic collections. This study suggests the need to further investigate the species richness and role of sessile rotifers in Mexican waterbodies.

\section{Acknowledgments}

M.A.J.S. thanks Posgrado en Ciencias del Mar y Limnología, UNAM and a scholarship from CONACyT (406417). S.S.S.S. and S.N. were supported by S.N.I. (18723 and 20520). Additional support was obtained from PAPIIT-IN214618 and IN219218. R.L.W. was supported, in part, by National Science Foundation (NSF) DEB 1257116.

\section{References}

Declerck, S.A.J. and S. Papakostas: Monogonont rotifers as model systems for study of micro-evolutionary adaptation and its ecoevolutionary implications. Hydrobiologia, 796, 131-144 (2017).

Dumont, H.J., I. Van De Velde and S. Dumont: Dry weight estimate of biomass in a selection of cladocera, copepoda and rotifera from plankton, periphyton and bentos of continental waters. Oecologia, 19, 75-97 (1975).

Edmondson, W.T.: Ecological studies of sessile Rotatoria. Part I. Factors affecting distribution. Ecological Monographs, 14, 31-66 (1944).

Edmondson, W.T.: Ecological studies of sessile Rotatoria. Part II: Dynamics of populations and social structures. Ecological Monographs, 15, 141-172 (1945).

Edmondson, W.T.:A graphical model for evaluating the use of the egg ratio for measuring birth and death rates. Oecologia, 1, 1-37 (1968).

Gao, Y.N., J. Dong, Q.Q. Fu, Y.P. Wangh, C. Chen, H.J. Li, R. Li and C.J. Zhou: Allelopathic effect of submerged macrophytes on phytoplankton. Allelopathy J., 40, 1-22 (2017).

García-Morales, A.E. and M. Elías-Gutiérrez: Rotifera from southeastern Mexico, new records and comments on zoogeography. Anales del instituto de Biologia, Universidad Nacional Autónoma de México. Serie Zoología, 75, 99-120 (2004).

Garraffoni, A.R.S. and A.P Laurenço: Synthesis of Brazilian Rotifera: An updated list of species. CheckList, 8, 375-407 (2012).

Garza-Mouriño, G. and M.E. Castellanos-Paez: Diversidad de rotíferos en los canales de la región noroeste de la zona chinampera de Xochimilco, Distrito Federal. In E. Stephan, El agua en la cuenca de Mexico. Universidad AutónomaMetropolitana, pp, 180-188 (2003).

Gladyshev, E. M. and Meselson: Extreme resistance of bdelloid rotifer to ionizing radiation. Proceedings of the National Academy of Science, 105, 5139-5144 (2008).

Harrod, J.J. and R.E. Hall: A method for determining the surface areas of various aquatic plants. Hydrobiologia, 20,173-178 (1962).

Jeppesen, E., M. Sondergaard, M. Sondergaard and K. Christofferson (Eds.): The structuring role of submerged macrophytes in lakes. New York, Springer (1998).

Jersabek, C.D.: Mongolian rotifers (Rotifera, Monogononta) - a checklist with annotations on global distribution and autecology. Proceedings of the Academy of Natural Sciences of Philadelphia, 159, 119-168 (2010).

Jersabek, C. D. and M.F. Leitner: The Rotifer World Catalog. World Wide Web Electronic Publication, Hydrobiologia, 796, 265-276 (2017).

Jiménez-Santos, M.A., S.S.S. Sarma and S. Nandini: Temperaturedependent demographic differences in sessile rotifers of the genus Limnias (Rotifera: Gnesiotrocha). J. Environ. Biol., 40, 711-718 (2019a).

Jiménez-Santos, M.A., S.S.S. Sarma, S. Nandini and R.L. Wallace: Sessile rotifers (Rotifera) exhibit strong seasonality in a shallow, eutrophic Ramsar site in Mexico. Invert. Biol., 138, e12270 (2019b).

Kordbacheh, A. and H. Rahimian: Annotated checklist of rotifers of Tehran Province, Iran, with notes on new records. Progr. Biol. Sci., 2, 59-67 (2012).

Kordbacheh, A., R.L. Wallace and E.J. Walsh: Evidence supporting cryptic species withing two sessile microinvertebrates, Limnias melicerta and L. ceratophylli (Rotifera, Gnesiotrocha). PLOS ONE, 10, e0205203 (2018).

Koste, W.: Über den Rotatorienbestand einer Mikrobiozönose in einem tropischen aquatischen Saumbiotop, der Eichhornia crassipes - Zone im Litoral des Bung - Borapet, einem Stausee in Zentralthailand. Gewässer Und Abwässer, 57, 43-58 (1975).

Koste, W.: Rotatoria. Die RädertiereMitteleuropas. Überordnung Monogononta. Begründet von M. Voigt GebrüderBorntraeger, Berlin, Stuttgart. I. Textbd. VIII + 1-673, II. Tafelbd. III + 1-476 (1978).

Lampert, W.: Zooplankton research: The contribution of limnology to general ecological paradigms. Aquatic Ecology, 31, 19-27 (1997).

Lobato-de Magalhães, T. and M. Martínez: Temporary freshwater wetlands floristics in central Mexico highlands. Botanical Sci., 96, 138-156 (2018). 
May, L.: Epizoic and parasitic rotifers. Hydrobiologia, 186, 59-67 (1989).

Meksuwan, P., R. Jaturapruek and S. Maiphae: Two new species of genus Limnias (Rotifera, Gnesiotrocha) from Thailand. Zookeys, 787, 1-15 (2018).

Meksuwan, P., P. Pholpunthin, E.J. Walsh, H. Segers and R.L. Wallace: Nestedness in sessile and periphytic rotifer communities: A metaanalysis. Int. Revi. Hydrobiol., 99, 1-10 (2014).

Meksuwan, P., P. Pholpuntin and H. Segers: Diversity of sessile rotifers (Gnesiotrocha, Monogononta, Rotifera) in ThaleNoi Lake, Thailand. Zootaxa, 2997, 1-18 (2011).

Meksuwan, P., P. Pholpunthin and H. Segers: The Collothecidae (Rotifera, Collothecacea) of Thailand, with the description of a new species and an illustrated key to the Southeast Asian fauna. ZooKeys, 315, 1-16 (2013).

Meksuwan, P., P. Pholpunthin and H. Segers: Molecular phylogeny confirms Conochilidae as ingroup of Flosculariidae (Rotifera, Gnesiotrocha). Zoologica Scripta, 44, 562-573 (2015).

Mills, S., J.A. Alcántara-Rodríguez, J. Ciros-Pérez, A. Gómez, A. Hagiwara, K.H. Galindo, C.D. Jersabek, R. Malekzadeh-Viayeh, F. Leasi, J.-S. Lee, D.B. Mark Welch, S. Papakostas, S. Riss, H. Segers, M. Serra, R. Shiel, R. Smolak, T.W. Snell, C.P. Stelzer, C.Q. Tang, R.L. Wallace, D. Fontaneto and E.J. Walsh: Fifteen species in one: Deciphering the Brachionus plicatilis species complex (Rotifera, Monogononta) through DNA taxonomy. Hydrobiologia, 796, 39-58 (2017).

Muñoz-Colmenares, M.E., S.S.S. Sarma and S. Nandini: Seasonal variations of rotifers from the high altitude Llano reservoir (State of Mexico, Mexico). J. Environ. Biol., 38 (Special Issue), 1171-1181 (2017).

Nandini, S., S.S.S. Sarma and R.D. Gulati: A seasonal study reveals the occurrence of exotic rotifers in the river Antigua, Veracruz, close to the Gulf of Mexico. River Res. Applicat., 33, 970-982 (2017).

Rao, T.R.: Population growth rate of the parasitic rotifer Proales gigantea, and susceptibility to parasitization in the snail Lymnaea acuminata at different stages of embryonic development. Hydrobiologia, 254, 1-6 (1993).

Rico-Martínez, R. and M. Silva-Briano: Contribution to the knowledge of the Rotifera of Mexico. Hydrobiologia, 255/256, 467-474 (1993).

Ríos-Arana, J.V., L. del C. Agüero-Reyes, R.L. Wallace and E.J. Walsh: Limnological characteristics and rotifer community composition of Northern Mexico Chihuahuan Desert Springs. J. Arid Enviro., 160, 32-41 (2019).

Rivas, Jr. J.A., J. Mohl, R.S. Van Pelt, M.-Y. Leung, R.L. Wallace, T.E. Gill and E.J. Walsh: Evidence for regional aeolian transport of freshwater biota in an arid region. Limno. Oceanogra. Lett., 3, 320-330 (2018).

Rivas, Jr., J.A., T. Schröder, T.E. Gill, R.L. Wallace and E.J. Walsh: Anemochory of diapausing stages of microinvertebrates in North American drylands. Freshwater Biol., 64,1303-1314 (2019).

Ruttner-Kolisko, A.: Suggestions for biomass calculation of planktonic rotifers. ArchivfürHydrobiologie-BeiheftErgebnisse der Limnologie, 8, 71-76 (1977).

Sa-Ardrit, P., P. Pholpunthin and H. Segers: A checklist of the freshwater rotifer fauna of Thailand (Rotifera, Monogononta, Bdelloidea). J. Limnol., 72, 361-375(2013).

Sarma, S.S.S.: Checklist of Rotifers (Rotifera) from Mexico. Environ. Ecol., 17, 978-983(1999).

Sarma, S.S.S. and M. Elías-Gutiérrez: Rotifer diversity in a central Mexican pond. Hydrobiologia, 387/388, 47-54 (1998).

Sarma, S.S.S. and M. Elías-Gutiérrez: A survey on the rotifer (Rotifera) fauna of Yucatan Peninsula (Mexico). Revista de Biología Tropical, 47, 191-200 (1999).
Sarma, S.S.S. and M. Elías-Gutiérrez: Rotifers from Mexico: New records in high altitude ponds. The Southwestern Naturalist, 45, 366-373 (2000).

Sarma, S.S.S., M.A. Jiménez-Santos, S. Nandini and R.L. Wallace: Demography of the sessile rotifers, Limnias ceratophylli and Limnias melicerta (Rotifera: Gnesiotrocha), in relation to food (Chlorella vulgaris Beijerinck, 1980) density. Hydrobiologia, 796, 181-189 (2017).

Sarma, S.S.S., S. Nandini and R.D. Gulati: Life history strategies of cladocerans: Comparisons of tropical and temperate taxa. Hydrobiologia, 542, 315-333 (2005a).

Sarma, S.S.S., R.D. Gulati and S. Nandini: Factors affecting egg-ratio in planktonic rotifers. Hydrobiologia, 546, 361-373 (2005b).

Sarma, S.S.S. and S. Nandini: Rotíferos Mexicanos (Rotifera). Estado de México. Manual de Enseñanza. Universidad Nacional Autónoma de México, Mexico City / Facultad de Estudios Superiores Iztacala, Tlalnepantla, pp. 1-148. ISBN. 978-607-028916-3 (2017).

Sarma, S.S.S. and S. Nandini: Allelopathic interactions in freshwater ecosystems with special reference to zooplankton. Chapter 11: In: Advances in Fish and Wildlife Ecology and Biology (Ed.: B.L. Kaul). Astral International Pvt. Ltd., New Delhi. pp. 195-221 (2018).

Segers, H.: Annotated checklist of the rotifers (Phylum Rotifera), with notes on nomenclature, taxonomy and distribution. Zootaxa, 1546, 1-104 (2007).

Segers, H., P. Meksuwan and L. Sanoamuang: New records of sessile rotifers (Phylum Rotifera: Flosculariacea, Collothecacea) from SoutheastAsia. Belgian J. Zool., 140, 235-240 (2010).

Sharma, B.K.: Rotifers (Rotifera: Eurotatoria) from wetlands of Majuli the largest river island, the Brahmaputra river of upper Assam, Northeast India. Check List, 10, 292-298 (2014).

Tiefenbacher, L.: Beiträge zur Biologie und Ökologie Sessiler Rotatorien Unter Besonderer Berücksichtigung des Gehäusebaues und der Regenerationsfähigkeit. Archivfür Hydrobiologie, 71, 31-78 (1972).

Torres-Orozco, R.E. and S.A. Zanatta: Species composition, abundance and distribution of zooplankton in a tropical eutrophic lake: Lake Catemaco, México. Revista de Biología Tropical, 46, 285-296 (1998).

Vilaclara, G. and V. Sladececk: Mexican rotifer as indicators of water quality with description of Collotheca riverai $\mathrm{n}$. sp. Archivfur. Hydrobiologie., 115, 257-263 (1989).

Van Donk, E. and W.J. Van de Bund: Impact of charophytes and other submerged macrophytes on phyto- and zooplankton communities: Allelophathy versus other mechanisms. Aquatic Botany, 72, 261-274 (2002).

Wallace, R.L.: Distribution of sessile rotifers in an acid bog pond. Archivfür Hydrobiologie, 19, 178-505 (1977).

Wallace, R.L.: Substrate selection by larvae of the sessile rotifer Ptygura beauchampi. Ecology, 59, 221-227 (1978).

Wallace, R.L.: Ecology of sessile rotifers. Hydrobiologia, 73, 181-193 (1980).

Wallace, R.L. and W.T. Edmondson: Mechanism and adaptive significance of substrate selection by a sessile rotifer. Ecology, 67, 314-323 (1986).

Wallace, R.L., A. Kordbacheh and E.J. Walsh: Key to the currently recognized species of Limnias Schrank, 1803 (Rotifera, Monogononta, Gnesiotrocha, Flosculariidae). Zootaxa, 4442, 307-318(2018).

Wallace, R.L., D.W. Ott, S.L. Stiles and C.K. Oldham-Ott: Bed and Breakfast: The parasitic life of Proales werneckii (Ploimida: Proalidae) within the alga Vaucheria (Xanthophyceae: 
Vaucheriales). Hydrobiologia, 446/447, 129-137 (2001).

Wallace, R.L., T.W. Snell and H.A. Smith: Phylum Rotifera. In: Thorp and Covich's Freshwater Invertebrates (Eds.: J.H. Thorp and D.C. Rogers) Elsevier, pp. 225-271 (2015).

Wallace, R.L., T.W. Snell, C. Ricciand T. Nogrady: Rotifera biology, ecology and systematics. Ghent, Belgium: Kenobi Productions (2006).

Wallace, R.L., T.W. Snell, E.J. Walsh, S.S.S. Sarma and H. Segers: Phylum Rotifera. In: Keys to Nearctic Fauna: Thorp and Covich's freshwater invertebrates (Eds.: J.H. Thorp \& D.C. Rogers), $4^{\text {th }}$ Edn., San Diego, CA: Academic Press, Elsevier, pp. 131-167 (2016).

Wallace, R.L., T. Snell, E.J. Walsh, S.S.S. Sarma and H. Segers: Phylum Rotifera. In: Keys to Palearctic Fauna: Thorp and Covich's Freshwater Invertebrates (Eds.: J.H. Thorp and D.C. Rogers) Elsevier, pp. 219-267 (2019).

Wallace, R.L., E.J. Walsh, R. Rico-Martínez, J.V. Ríos-Arana and T. Schröder: Species composition and distribution of rotifers in Chihuahuan desert waters: Is everything everywhere? International Association of Theoretical and Applied Limnology, $30,73-76(2008)$.
Walsh, J.: Rotifers: Nature's water purifiers. National Geographic, 155, 287-292 (1979).

Walsh, E.J.: Habitat-specific predation susceptibilities of a littoral rotifer to two invertebrate predators. Hydrobiologia, 313/314, 205-211 (1995).

Walsh, E.J., L. May and R.L. Wallace: A metadata approach to documenting sex in phylum Rotifera: Diapausing embryos, males, and hatchlings from sediments. Hydrobiologia, 796, 265-276 (2017).

Walsh, E.J., T. Schröder, R.L. Wallace, J.V. Ríos-Arana and R. RicoMartínez: Rotifers from selected inland saline waters in the Chihuahuan Desert of México. Saline Systems, 4, 7 (2008).

Watala, K.B. and C. Watala: A photometric technique for the measurement of plant adsorption of Brilliant Blue dye on to plant surfaces. Freshwater Biology, 31, 175-181 (1994).

Young, A., R. Hochberg, E.J. Walsh and R.L. Wallace: Modeling the life history of sessile rotifers: Larval substratum selection through reproduction. Hydrobiologia, 844, 67-82 (2019).

Zelditch, M.L., D. L. Swiderski and H. D. Sheets: Geometric morphometrics for biologists: a primer. Elsevier, London (2012). 